Becoming Sinners 


\section{ETHNOGRAPHIC STUDIES IN SUBJECTIVITY}

Tanya Luhrmann and Steven Parish, Editors

I. Forget Colonialism? Sacrifice and the Art of Memory in Madagascar, by Jennifer Cole

2. Sensory Biographies: Lives and Deaths among Nepal's Yolmo Buddhists, by Robert Desjarlais

3. Culture and the Senses: Bodily Ways of Knowing in an African Community, by Kathryn Linn Geurts

4. Becoming Sinners: Christianity and Moral Torment in a Papua New Guinea Society, by Joel Robbins 


\section{Becoming Sinners}

Christianity and Moral Torment in a Papua New Guinea Society

\section{Joel Robbins}


Parts of chapter 4 originally appeared in slightly different form in "Secrecy and the Sense of an Ending: Narrative, Time, and Everyday Millenarianism in Papua New Guinea and in Christian Fundamentalism," Comparative Studies in Society and History 43 (3): 525-5I (200I). Reprinted with the permission of Cambridge University Press.

Parts of chapter 4 also originally appeared in slightly different form in "On Reading 'World News': Apocalyptic Narrative, Negative Nationalism, and Transnational Christianity in a Papua New Guinea Society," Social Analysis 42 (2): 103-30 (1998). Reprinted with permission.

Parts of chapters 5, 6, and 7 appeared in different form in "Becoming Sinners: Christianity and Desire among the Urapmin of Papua New Guinea," Ethnology 37 (4): 299-3 I 6 (I998), and in "Dispossessing the Spirits: Christian Transformations of Desire and Ecology among the Urapmin of Papua New Guinea," Ethnology 34 (3): 2I I-24 (I995). Reprinted with permission.

Parts of chapter 8 originally appeared in slightly different form in "My Wife Can't Break Off Part of Her Belief and Give It to Me: Apocalyptic Interrogations of Christian Individualism among the Urapmin of Papua New Guinea," Paideuma 48: 189-206 (2002). Reprinted with permission.

University of California Press

Berkeley and Los Angeles, California

University of California Press, Ltd.

London, England

(C) 2004 by the Regents of the University of California

\section{Library of Congress Cataloging-in-Publication Data}

Robbins, Joel, I96I-.

Becoming sinners : Christianity and moral torment in a Papua New Guinea society / Joel Robbins.

p. $\quad \mathrm{cm}$. (Ethnographic studies in subjectivity ; 4) Includes bibliographical references and index.

ISBN 0-520-23799-4 (cloth : alk. paper).ISBN 0-520-23800-I (pbk. : alk. paper)

I. Christianity-Papua New Guinea-Urapmin. 2. Urapmin (Papua New Guinea)-Religious life and customs. I. Title. II Series.

BRI495.N5 R63 2004

$306.6^{\prime} 09957^{\prime} 7$ - dc2I

Manufactured in the United States of America

$\begin{array}{lllllllll}\text { I2 II } & \text { IO } & 09 & 08 & 07 & 06 & 05 & 04\end{array}$

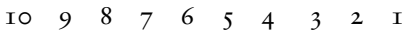

The paper used in this publication is both acid-free and totally chlorine-free (TCF). It meets the minimum requirements of ANSI/NISO Z39.48-I992 (R I997)

(Permanence of Paper). 
For Liz and Hannah 
This page intentionally left blank 